\title{
ENVIRONMENT FRIENDLY SALT COATING FOR ROOT PRUNING OF SWEET PEPPER SEEDLINGS
}

Surendra Lal Shrestha*1 and Won-Hee Kang ${ }^{2}$

\begin{abstract}
This study was done to minimize excessive growth and root mat formation which is a problem during preparation of seedlings in sweet pepper (Capsicum annuum L.) seedlings. The experiment was laid out in a completely randomized design (CRD) with 3 replications. Hybrid CV. 'Sonik' seeds were planted in plug trays coated with latex paint containing $0 \%$, $1 \%, 3 \%, 5 \%, 7 \%, 10 \%$ and $15 \% \mathrm{NaCl}(\mathrm{w} / \mathrm{v})$ and compared with an uncoated control. Results showed that $\mathrm{NaCl}$ coating significantly minimized excessive growth rate and root mat formation. Seedlings from the treatment produced more fibrous roots. Even though before transplanting, untreated seedlings were taller with longer root length, significantly higher fresh and dry weight of shoots and roots; after transplanting, seedlings from $\mathrm{NaCl}$ coated trays showed better performance with taller plants, longer roots, and higher fresh and dry weights of shoots and roots. The $7 \% \mathrm{NaCl}$ treatment gave superior performance among the treated and control plants.
\end{abstract}

Key words: chemical pruning, excessive growth, root and shoot growth, root mat formation,

\section{INTRODUCTION}

Sweet pepper (Capsicum annuum L.) is an important vegetable crop in Korea. Most Korean vegetable nurseries use plastic plug trays for seedling production. Plastic plug trays have numerous production and marketing advantages but a major problem is root mat formation. After transplanting, roots continue to follow circular growth while slowly expanding radially into the soil. The eventual result is a weakened plant with increased mortality, that is clearly unsuitable for sale (Arnold and Young, 1991; Beeson and Newton,1992). A major problem with conventional seedling production in plastic plug trays includes root spiraling and roots egressing into the nursery beds. It results in seedlings with deformed, damaged or poorly developed root systems that can decrease survival and growth of transplanted plants (Stein, 1978). However, nursery techniques that produce well-developed fibrous root systems contribute to overall improved seedling survival and growth (Devey, 1984; Struve, 1993). Since the 1960s, chemical root pruning with copper has been used in forestry and ornamental nurseries (Beeson and Newton, 1992; Saul, 1968). Struve et al. (1994) demonstrated that copper hydroxide was effective in controlling root spiraling in plastic containers. Hudson et al. (2002) also mentioned that chemical root pruning involves treating the interior container wall with a growth inhibiting chemical i.e. copper hydroxide. This causes the lateral roots to be chemically pruned at the container wall and a well branched root system occurs, which enhances transplant establishment (Hudson et al. 2002). Similarly, Yeoung et al. (2001) found the optimum concentration of copper for coating plug trays to prevent root circling and to promote growth of sweet pepper appeared to be $10 \%(\mathrm{v} / \mathrm{v})$ copper. However, the high concentration coating induced serious damage to root structure, resulting in delayed root growth in field after transplanting.

$\mathrm{Cu}$ and $\mathrm{Co}$ were the best heavy metals for inducing root pruning, while at the same time, minimally affecting subsequent shoot growth (Backer et al., 1995). Approximately 70 elements are classified as heavy metals based on the classical definition of a specific gravity of greater than $5 \mathrm{~g} \mathrm{~cm}-3$. Currently, however, the term heavy metals is restricted to

\footnotetext{
${ }^{1}$ Senior Scientist, Nepal Agriculture Research Council, Singh Durbar Plaza, Kathmandu, Nepal

2 Professor, Kangwon National University, Republic of Korea.
} 
elements commonly considered as pollutants (De Filippis and Pallaghy, 1994). In using potentially toxic chemicals (like heavy metals) to try to control root growth in containers, there is the danger of releasing heavy metals into the environment. There is ample evidence that all of the heavy metals used pose a danger to the environment. The general order of toxicity of these metals in the environment is $\mathrm{Sr}<\mathrm{Co}<\mathrm{Zn}<\mathrm{Cu}<\mathrm{Ni}<\mathrm{Pb}$ (Shaw, 1989). Therefore, a commonly available nonpolluting chemical root pruning technique is required to solve this problem. $\mathrm{NaCl}$ is one of the essential salts for human beings, is abundant in nature, and poses little risk to the environment when used in small quantities. Therefore, the objectives of this study were to evaluate whether sea salt $(\mathrm{NaCl})$ coating on plastic plug trays minimizes root mat (root circling and moving upward formation, whether it enhances seedling growth after transplanting, and to determine the optimum concentration of $\mathrm{NaCl}$ coating

\section{MATERIALS AND METHODS}

This experiment was carried out at the Deep Sea Water Research Farm, Hwacheon. The experiment was conducted in greenhouse nursery beds using plastic plug trays $(54 \mathrm{~cm}$ in length and $28 \mathrm{~cm}$ in width) which contained 32 plugs. Seedlings were later transplanted on plastic pots $(20 \mathrm{~cm}$ in diameter and $16 \mathrm{~cm}$ in height; $4.0 \mathrm{~L}$ in volume) filled with sandy soil where water and fertilizer was applied through drip irrigation system.

\section{NACL COATING TREATMENTS}

The wall of the plug trays were coated on the interior with nontoxic water based latex

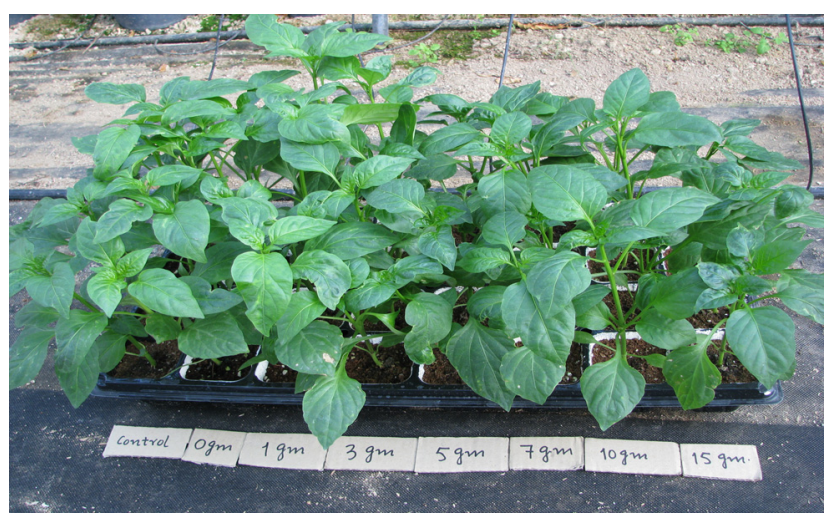
carrier paint containing sea salt $(\mathrm{NaCl}) ; 0 \%, 1 \%, 3 \%, 5 \%, 7 \%, 10 \%$ and $15 \%(\mathrm{w} / \mathrm{v})$ (Fig.1). There was also an uncoated control. Hybrid CV. 'Sonik' seeds were sown one per plug filled with horticulture soil (Sangtho, Seminis Korea) on nursery bed under greenhouse in December 2007. Greenhouse temperature ranged from 18 to $25{ }^{\circ} \mathrm{C}$. The experiment was laid out using a completely randomized design with 3 replications and 8 treatments.

Fig. 1: Inner wall of plastic plug tray coated with $\mathrm{NaCl}$ by dissolving $1 \mathrm{~g}, 3 \mathrm{~g}, 5 \mathrm{~g}, 7 \mathrm{~g}, 10 \mathrm{~g}$, and $15 \mathrm{~g}$ in $100 \mathrm{ml}$ latex-based paint. Seedlings were grown in these plugs filled with horticulture soil.

\section{ROOT AND SHOOT GROWTH MEASUREMENT}

Growth responses of seedlings such as plant height, fresh weight and dry weight of above ground parts and roots were observed at 7 days intervals from 28 days after sowing (DAS) to 42 DAS. Thirty-five day old seedlings were transplanted to plastic pots for evaluation of growth potential, after which the same parameters were observed: plant height, fresh and dry weight of above-ground parts and roots were recorded on 35 days after transplanting (DAT). Plant height was measured from soil surface to its tip of the shoot. Root length determinations were made by removing seedlings carefully from the plug cell, gently washing the root system in water, and determining root length from soil surface to the tip of the taproot. Fresh weight was taken just after cutting the shoot and roots separately. The fresh samples were dried until dry weight stabilized to determine dry weights. Shoot: 
root ratio was calculated from the dry weight of shoots and roots, respectively. All results represent the means of 12 individual plants per treatment per replication.

The collected data were analyzed using Fisher's analysis of variance under completely randomized design (CRD) with MSTATC software program; the treatments means were compared by Duncan multiple range test (DMRT) at 0.05 probability level (Steel and Torri, 1984).

\section{RESULTS AND DISCUSSIONS}

\section{ROOT AND SHOOT GROWTH OF SEEDLINGS IN PLASTIC PLUG TRAYS}

Plant height was measured on 28, 35, and 42 DAS. In all these observations, $\mathrm{NaCl}$ significantly reduced the plant height (Table 1). At 28 DAS, significant height reduction was only observed with the $15 \% \mathrm{NaCl}$ treatment, but for later harvest dates, significant effects were observed for lower $\mathrm{NaCl}$ concentrations also. At $35 \mathrm{DAS}, \mathrm{NaCl}$ concentrations greater than $1 \%$ showed growth inhibition; at $42 \mathrm{DAS}$, more than $5 \% \mathrm{NaCl}$ showed significant growth inhibition. Therefore, $\mathrm{NaCl}$ affected root growth whenever root tips came in contact with the $\mathrm{NaCl}$ coat and root growth was reduced. As the reduced roots could not absorb as much nutrients from the soil, plant height was reduced accordingly. Hence, the tallest seedlings were obtained in the $0 \% \mathrm{NaCl}$ treatment on all observation days (Table 1).

Table 1: Effect of $\mathrm{NaCl}$ coated plastic plug tray on shoot and root growth of sweet pepper seedlings

\begin{tabular}{llllll}
\hline \multirow{2}{*}{ Treatment } & \multicolumn{3}{c}{ Plant height $(\mathrm{cm})$} & \multicolumn{2}{c}{ Root length $(\mathrm{cm})$} \\
\cline { 2 - 6 } & $28 \mathrm{DAS}$ & $35 \mathrm{DAS}$ & $42 \mathrm{DAS}$ & $28 \mathrm{DAS}$ & $42 \mathrm{DAS}$ \\
\hline Control & $13.0 \mathrm{a}^{\mathrm{z}}$ & $17.1 \mathrm{a}$ & $18.9 \mathrm{bc}$ & $15.4 \mathrm{a}$ & $16.3 \mathrm{a}$ \\
$0 \% \mathrm{NaCl}$ & $12.2 \mathrm{ab}$ & $17.3 \mathrm{a}$ & $22.3 \mathrm{a}$ & $16.3 \mathrm{a}$ & $16.4 \mathrm{a}$ \\
$1 \% \mathrm{NaCl}$ & $12.1 \mathrm{ab}$ & $16.6 \mathrm{a}$ & $20.7 \mathrm{ab}$ & $15.7 \mathrm{a}$ & $16.7 \mathrm{a}$ \\
$3 \%$ & $11.3 \mathrm{ab}$ & $15.0 \mathrm{~b}$ & $20.3 \mathrm{ab}$ & $14.0 \mathrm{a}$ & $14.4 \mathrm{a}$ \\
$5 \%$ & $10.6 \mathrm{ab}$ & $12.6 \mathrm{c}$ & $17.6 \mathrm{~cd}$ & $13.3 \mathrm{a}$ & $15.5 \mathrm{a}$ \\
$7 \%$ & $12.3 \mathrm{ab}$ & $14.7 \mathrm{~b}$ & $18.9 \mathrm{bc}$ & $13.8 \mathrm{a}$ & $15.4 \mathrm{a}$ \\
$10 \%$ & $10.6 \mathrm{ab}$ & $14.1 \mathrm{bc}$ & $15.7 \mathrm{de}$ & $13.4 \mathrm{a}$ & $15.4 \mathrm{a}$ \\
$15 \%$ & $10.0 \mathrm{~b}$ & $11.0 \mathrm{~d}$ & $15.1 \mathrm{e}$ & $14.2 \mathrm{a}$ & $14.0 \mathrm{a}$ \\
$\mathrm{CV}(\%)$ & 10.2 & 4.46 & 4.64 & 11.8 & 8.2 \\
\hline
\end{tabular}

${ }^{\mathrm{z}}$ Mean separation within columns by Duncan's multiple range test

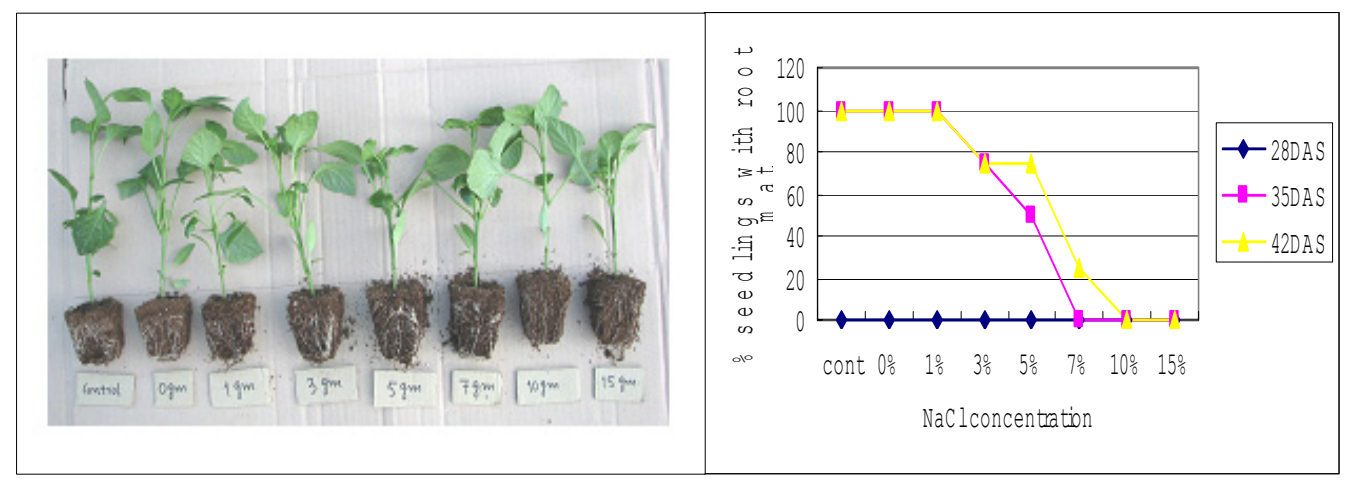

Fig.2: Effect of $\mathrm{NaCl}$ treatment on root mat formation; A: shoot and root growth on 35 DAS. B: Seedlings (\%) with root mat formed on 28 DAS, 35 DAS, and 42 DAS.

Root length was measured at 28 DAS and 42 DAS but there was no significant effect of $\mathrm{NaCl}$. However, as dose of $\mathrm{NaCl}$ concentration increased, root mat formation was decreased after 
35 DAS (Fig.2). Observation of root mat formation on the side and bottom of the plug cell showed that first root mat formation took place in the bottom of the plug close to the drainage hole and later on the side wall, and it spread as the seedling age becoming older. At $28 \mathrm{DAS}$, no root mat formation was observed. However, on $35 \mathrm{DAS}, \geq 1 \% \mathrm{NaCl}$ minimized bottom mat formation whereas $\geq 5 \% \mathrm{NaCl}$ eliminated side mat formation. Likewise, at 42 DAS, $\geq 3 \% \mathrm{NaCl}$ minimized side mat formation (only $25 \%$ of seedlings had side mat) and $10 \%$ to $15 \% \mathrm{NaCl}$ showed no side root mat formation (Fig.2).

The $\mathrm{NaCl}$ treatments did not significantly affect fresh weight of shoots and roots at 28 DAS (Table 2). At $35 \mathrm{DAS}$, all $\mathrm{NaCl}$ treatments significantly reduced the shoot fresh weights, e.g. the $7 \% \mathrm{NaCl}$ treatment and control had $4.58 \mathrm{~g}$ and $6.63 \mathrm{~g}$, respectively (Table 2). Likewise, at $42 \mathrm{DAS}, \geq 7 \% \mathrm{NaCl}$ significantly reduced the shoot fresh weight, indicating that $\mathrm{NaCl}$ had decreased both plant height and shoot fresh weight (Table 2).

Table 2: Effect of $\mathrm{NaCl}$ coated plastic plug tray on fresh weight of above ground and root of seedlings

\begin{tabular}{lllllll}
\hline \multirow{2}{*}{ Treatment } & \multicolumn{3}{c}{ Above ground fresh weight $(\mathrm{g})$} & \multicolumn{3}{c}{ Root fresh weight (g) } \\
\cline { 2 - 7 } & $28 \mathrm{DAS}$ & 35DAS & $42 \mathrm{DAS}$ & 28DAS & $35 \mathrm{DAS}$ & 42DAS \\
\hline Control & $4.80 \mathrm{ab}^{\mathrm{z}}$ & $6.63 \mathrm{a}$ & $7.13 \mathrm{ab}$ & $1.33 \mathrm{ab}$ & $1.96 \mathrm{a}$ & $2.28 \mathrm{a}$ \\
$0 \% \mathrm{NaCl}$ & $5.18 \mathrm{a}$ & $6.11 \mathrm{ab}$ & $8.39 \mathrm{a}$ & $1.63 \mathrm{a}$ & $1.53 \mathrm{~b}$ & $2.25 \mathrm{a}$ \\
$1 \% \mathrm{NaCl}$ & $4.77 \mathrm{ab}$ & $5.76 \mathrm{~b}$ & $7.45 \mathrm{ab}$ & $1.33 \mathrm{ab}$ & $1.55 \mathrm{~b}$ & $1.82 \mathrm{ab}$ \\
$3 \%$ & $4.14 \mathrm{ab}$ & $4.90 \mathrm{c}$ & $7.09 \mathrm{ab}$ & $1.12 \mathrm{~b}$ & $1.40 \mathrm{bc}$ & $1.69 \mathrm{ab}$ \\
$5 \%$ & $3.69 \mathrm{ab}$ & $4.10 \mathrm{~d}$ & $5.88 \mathrm{bc}$ & $0.99 \mathrm{~b}$ & $1.44 \mathrm{bc}$ & $1.43 \mathrm{~b}$ \\
$7 \%$ & $4.37 \mathrm{ab}$ & $4.58 \mathrm{~cd}$ & $6.89 \mathrm{ab}$ & $1.19 \mathrm{ab}$ & $1.39 \mathrm{bc}$ & $1.73 \mathrm{ab}$ \\
$10 \%$ & $3.69 \mathrm{ab}$ & $4.53 \mathrm{~cd}$ & $4.97 \mathrm{~cd}$ & $0.96 \mathrm{~b}$ & $1.22 \mathrm{bc}$ & $1.29 \mathrm{~b}$ \\
$15 \%$ & $3.32 \mathrm{~b}$ & $3.37 \mathrm{e}$ & $3.86 \mathrm{~d}$ & $0.93 \mathrm{~b}$ & $1.11 \mathrm{c}$ & $1.20 \mathrm{~b}$ \\
$\mathrm{CV}(\%)$ & 15.89 & 5.74 & 10.82 & 16.49 & 13.92 & 15.63 \\
\hline $\mathrm{z}$ & &
\end{tabular}

${ }^{\mathrm{z}}$ Mean separation within columns by Duncan's multiple range test

At 35 DAS, all $\mathrm{NaCl}$ treatments significantly lowered the root fresh weight compared to the $0 \%$ control. The $7 \% \mathrm{NaCl}$ treatment had $9 \%$ less fresh weight as compared to the control, whereas at $42 \mathrm{DAS} \geq 3 \% \mathrm{NaCl}$ significantly reduced fresh weights. The reduced root weights corresponded with reduced shoot fresh weights because at 35 DAS, most of the $\mathrm{NaCl}$ treatments significantly reduced both root and shoot fresh weights. Hence, the treatment


effects were most apparent between 28 to 42 DAS. Similarly, on 42 DAS, all $\mathrm{NaCl}$-containing treatments reduced root fresh weights, whereas differences were significant for $5 \%$ and $>7 \%$ $\mathrm{NaCl}$. As the percentage of root mats was higher for the control and $0 \%$ $\mathrm{NaCl}$, fresh root weights for these two treatments were also higher.

Fig.3: Effect of $\mathrm{NaCl}$ treatment on percent dry matter of roots at $35 \mathrm{DAS}$ and $42 \mathrm{DAS}$.

When shoots were dried at 28 DAS and 42 DAS, no significant differences in dry weights were noticed. With regard to percentage dry matter, $\mathrm{NaCl}$-treated seedlings had higher percentage dry matter content as compared to the control (Fig.3). This verified that $\mathrm{NaCl}$ treated seedlings contained less water (\%). On $35 \mathrm{DAS}$, all the $\mathrm{NaCl}$ treated seedlings had 
less dry matter weight as compared to controls. The difference between the control and $7 \%$ $\mathrm{NaCl}$ was $250 \mathrm{mg}$ (Table 3) in shoot dry weight. However, the effects of $\mathrm{NaCl}$ on reduced root dry weight were significant across all harvest dates. The reductions in root dry weights were not significant for $\mathrm{NaCl}$ treatments $<7 \%$ on dates 28 DAS and 42 DAS. However, $\geq 7 \%$ $\mathrm{NaCl}$ treated seedlings had significantly lowered dry root weight as compared to control. On $35 \mathrm{DAS}, 7 \% \mathrm{NaCl}$ gave $132 \mathrm{mg}$ whereas control had $231 \mathrm{mg}$ (Table 3) (incomplete sentence).

Table 3: Effect of $\mathrm{NaCl}$ coated plastic plug tray on dry weight of above ground and root of sweet pepper seedlings

\begin{tabular}{lllllll}
\hline \multirow{2}{*}{ Treatment } & \multicolumn{3}{c}{ Dry weight of shoots $(\mathrm{mg})$} & \multicolumn{3}{c}{ Dry weight of roots $(\mathrm{mg})$} \\
& 28DAS & 35DAS & 42DAS & 28DAS & 35DAS & 42DAS \\
\hline Control & $460 \mathrm{a}^{\mathrm{z}}$ & $745 \mathrm{a}$ & $895 \mathrm{ab}$ & $151 \mathrm{ab}$ & $231 \mathrm{a}$ & $244 \mathrm{ab}$ \\
$0 \% \mathrm{NaCl}$ & $480 \mathrm{a}$ & $630 \mathrm{~b}$ & $985 \mathrm{a}$ & $166 \mathrm{a}$ & $165 \mathrm{~b}$ & $249 \mathrm{a}$ \\
$1 \%$ & $445 \mathrm{a}$ & $605 \mathrm{~b}$ & $870 \mathrm{abc}$ & $141 \mathrm{abc}$ & $161 \mathrm{bc}$ & $207 \mathrm{bc}$ \\
$3 \%$ & $390 \mathrm{a}$ & $525 \mathrm{c}$ & $910 \mathrm{ab}$ & $115 \mathrm{bcd}$ & $153 \mathrm{bcd}$ & $194 \mathrm{~cd}$ \\
$5 \%$ & $355 \mathrm{a}$ & $455 \mathrm{~cd}$ & $765 \mathrm{abc}$ & $97 \mathrm{~cd}$ & $139 \mathrm{bcd}$ & $174 \mathrm{cde}$ \\
$7 \%$ & $425 \mathrm{a}$ & $495 \mathrm{c}$ & $945 \mathrm{a}$ & $122 \mathrm{abcd}$ & $132 \mathrm{bcd}$ & $212 \mathrm{abc}$ \\
$10 \%$ & $360 \mathrm{a}$ & $485 \mathrm{c}$ & $615 \mathrm{c}$ & $94 \mathrm{~cd}$ & $113 \mathrm{~cd}$ & $144 \mathrm{e}$ \\
$15 \%$ & $320 \mathrm{a}$ & $390 \mathrm{~d}$ & $665 \mathrm{bc}$ & $92 \mathrm{~d}$ & $104 \mathrm{~d}$ & $161 \mathrm{de}$ \\
$\mathrm{CV}(\%)$ & 14.02 & 5.04 & 13.07 & 16.3 & 14.2 & 8.03 \\
\hline $\mathrm{z}$ & &
\end{tabular}

${ }^{\mathrm{z}}$ Mean separation within columns by Duncan's multiple range test

\section{SHOOT AND ROOT GROWTH OF SEEDLINGS AFTER TRANSPLANTING}

Thirty five day old seedlings from the experiment were transplanted into pots and root and shoot growth observations were taken at 35 DAT. There were no significant differences in height between control and $\mathrm{NaCl}$-treated plants except for reduced height in the $15 \% \mathrm{NaCl}$ treatment. The plant height of $33.2 \mathrm{~cm}$ for $7 \% \mathrm{NaCl}$ was at par to control $(33.7 \mathrm{~cm})$ (Table 4). The starting height at transplanting of these seedlings from $\mathrm{NaCl}$ coated plugs were significantly shorter than control seedlings for all except $1 \% \mathrm{NaCl}$ treatment. The $7 \% \mathrm{NaCl}$ treated seedlings were shorter by $2.4 \mathrm{~cm}$ than control (Table 1) at transplanting. However,

Table 4: Effect of $\mathrm{NaCl}$ coated plastic plug tray on shoot and root growth of sweet pepper seedlings at 35days after transplanting

\begin{tabular}{lllllll}
\hline Treatments & $\begin{array}{l}\text { Plant } \\
\text { height }(\mathrm{cm})\end{array}$ & $\begin{array}{l}\text { Root length } \\
(\mathrm{cm})\end{array}$ & $\begin{array}{l}\text { Above ground } \\
\text { fresh weight }(\mathrm{g})\end{array}$ & $\begin{array}{l}\text { Root fresh } \\
\text { weight }(\mathrm{g})\end{array}$ & $\begin{array}{l}\text { Above ground } \\
\text { dry weight }(\mathrm{g})\end{array}$ & $\begin{array}{l}\text { Root dry } \\
\text { weight }(\mathrm{g})\end{array}$ \\
\hline Control & $33.7 \mathrm{az}$ & $25.3 \mathrm{ab}$ & $32.81 \mathrm{ab}$ & $8.61 \mathrm{ab}$ & $3.36 \mathrm{a}$ & $0.78 \mathrm{a}$ \\
$0 \% \mathrm{NaCl}$ & $31.9 \mathrm{bc}$ & $25.5 \mathrm{ab}$ & $31.31 \mathrm{ab}$ & $8.54 \mathrm{ab}$ & $3.29 \mathrm{a}$ & $0.86 \mathrm{a}$ \\
$1 \% \mathrm{NaCl}$ & $30.7 \mathrm{~cd}$ & $23.6 \mathrm{~b}$ & $28.18 \mathrm{~b}$ & $7.38 \mathrm{ab}$ & $2.96 \mathrm{ab}$ & $0.74 \mathrm{ab}$ \\
$3 \%$ & $33.1 \mathrm{ab}$ & $27.2 \mathrm{ab}$ & $32.71 \mathrm{ab}$ & $8.35 \mathrm{ab}$ & $3.36 \mathrm{a}$ & $0.83 \mathrm{a}$ \\
$5 \%$ & $33.0 \mathrm{ab}$ & $28.1 \mathrm{a}$ & $32.09 \mathrm{ab}$ & $8.08 \mathrm{ab}$ & $3.32 \mathrm{a}$ & $0.78 \mathrm{a}$ \\
$7 \%$ & $33.2 \mathrm{ab}$ & $26.2 \mathrm{ab}$ & $35.13 \mathrm{a}$ & $9.41 \mathrm{a}$ & $3.51 \mathrm{a}$ & $0.85 \mathrm{a}$ \\
$10 \%$ & $33.3 \mathrm{ab}$ & $25.1 \mathrm{ab}$ & $34.19 \mathrm{a}$ & $8.43 \mathrm{ab}$ & $3.44 \mathrm{a}$ & $0.77 \mathrm{a}$ \\
$15 \%$ & $29.7 \mathrm{~d}$ & $24.3 \mathrm{ab}$ & $27.86 \mathrm{~b}$ & $6.56 \mathrm{~b}$ & $2.60 \mathrm{~b}$ & $0.61 \mathrm{~b}$ \\
$\mathrm{CV}(\%)$ & 2.03 & 6.38 & 7.41 & 12.43 & 8.80 & 8.43 \\
\hline
\end{tabular}

${ }^{\mathrm{z}}$ Mean separation within columns by Duncan's multiple range test

at 35 DAT no differences in height were observed. However, increments of plant height by 35 DAT were higher in treatments from $>1 \% \mathrm{NaCl}$ treated seedlings. Therefore, $\mathrm{NaCl}$ coating of seedling trays did not show adverse effects on post-transplanting height. Similarly, no significant differences were observed in root length among treated and untreated plants by 35 DAT. However, seedlings from $5 \% \mathrm{NaCl}$ had the longest root length $(28.1 \mathrm{~cm})$ followed by $3 \% \mathrm{NaCl}(27.2 \mathrm{~cm})$, whereas control had roots of $25.3 \mathrm{~cm}$ (Table 4). Before transplanting, 


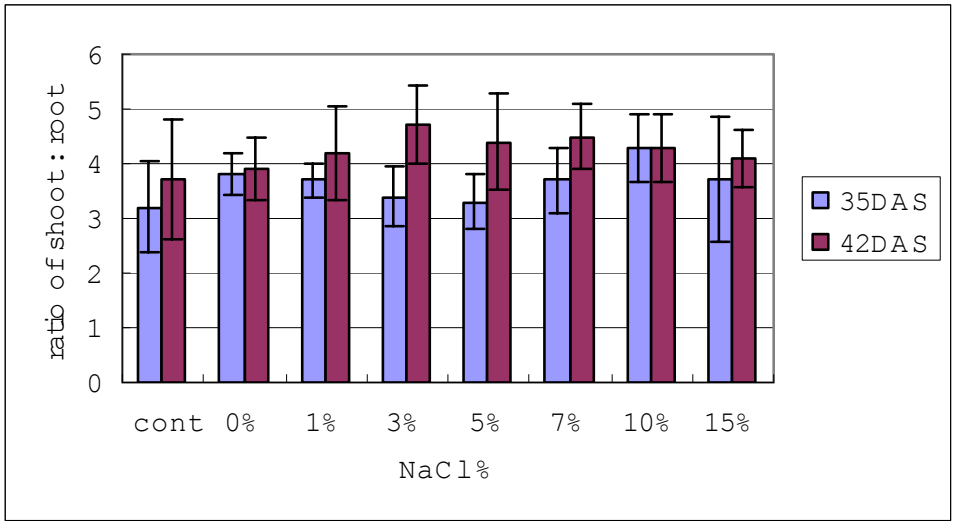

most of the $\mathrm{NaCl}$ treatment seedlings had shorter roots. The incremental growth of roots at 35 DAT was higher in $3 \%, 5 \%, 7 \%$ and $10 \% \mathrm{NaCl}$ treated seedlings as compared to control $(8.2 \mathrm{~cm})$. It showed that after transplanting, roots from $\mathrm{NaCl}$-treated plug trays grew faster than those from the control.

Fig.4: Shoot: root ratios on dry matter basis. Vertical bars indicate standard deviation.

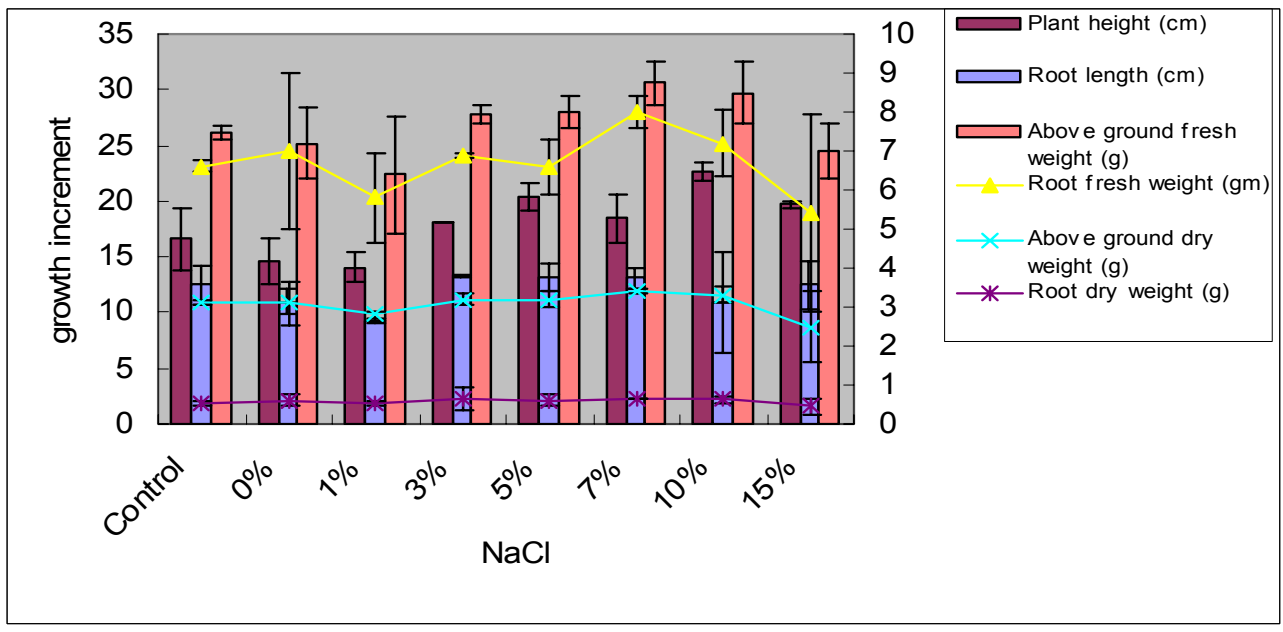

Fig.5: Increment in shoot and root growth at 35 DAT as compared to size at transplanting (35 DAS). Vertical bars indicate standard deviation.

No significant difference was observed in above-ground fresh weights at 35 DAT between $\mathrm{NaCl}$ and control treatments except for the $15 \% \mathrm{NaCl}$ treatment. Plants from $7 \% \mathrm{NaCl}$ had the highest above ground fresh weight $(35.1 \mathrm{~g})$ followed by $10 \% \mathrm{NaCl}(34.2 \mathrm{~g})$, whereas the control had $32.8 \mathrm{~g}$. At the time of transplanting (35 DAS), all seedlings from $\mathrm{NaCl}$ treatments had significantly lower shoot fresh weights, but at $35 \mathrm{DAT}, 7 \%$ and $10 \% \mathrm{NaCl}$ had higher shoot fresh weights as compared to control (Table 4). The growth increment in shoot fresh weights at 35 DAT was higher in 3\%, 5\%, 7\% and $10 \% \mathrm{NaCl}$-treated seedlings as compared to control (Fig.5). Hence, $\mathrm{NaCl}$ treated seedlings gave faster growth rate after transplanting. Similarly, no significant differences were noticed in root fresh weights, but $7 \% \mathrm{NaCl}$ treatment gave the highest root fresh weight compared to the control (Table 4). At the time of transplanting (35 DAS), the control treatment had the highest root fresh weight. The root mat formation in control seedlings may not have been favorable for subsequent active growth of the roots after transplanting. Likewise, when fresh above ground parts and roots were dried on 35 DAT, no significant differences were noticed between treated and non-treated seedlings. However, the highest above ground dry weights were obtained from $7 \% \mathrm{NaCl}(3.51 \mathrm{~g})$ followed by $10 \% \mathrm{NaCl}(3.44 \mathrm{~g})$ treatments, whereas control plants were $3.36 \mathrm{~g}$ (Table 4). Non-treated seedlings were lower in shoot root ratio as compared to 
treated seedlings (Fig.4). Incremental growth of shoot dry weights at 35 DAT was higher in $3 \%, 5 \%, 7 \%$ and $10 \% \mathrm{NaCl}$-treated seedlings as compared to the control (Fig.5), even though at the time of transplanting (35 DAS), plants from control had significantly higher dry weight. Similarly, among the seedlings from $\mathrm{NaCl}$-coated trays, $7 \% \mathrm{NaCl}$ gave the highest root dry weights $(0.85 \mathrm{~g})$ whereas the control had $0.78 \mathrm{~g}$ (Table 4$)$. Incremental growth in root dry weights at 35 DAT were higher in 3\%, 5\%, $7 \%$ and $10 \% \mathrm{NaCl}$-treated seedlings as compared to control (Fig.5). Hence, after transplanting, $\mathrm{NaCl}$ coated seedlings showed better performance and faster growth rate.

\section{CONCLUSIONS}

On the basis of the above-mentioned results, it can be concluded that; even though before transplanting, untreated seedlings were taller and had longer root length, significantly higher fresh and dry weight of shoot and root, after transplanting, seedlings from $\mathrm{NaCl}$ coated trays showed better performance with taller plants, longer roots, higher fresh and dry weights of shoots and roots. The $7 \% \mathrm{NaCl}$ treatment gave the best performance among the treatments. Therefore, the optimum concentration of $\mathrm{NaCl}$ in latex plug tray coating to minimize root mat formation and optimize post-transplanting growth appeared to be $7 \%$ $(\mathrm{w} / \mathrm{v}) \mathrm{NaCl}$.

\section{REFERENCES}

Arnold, M. A. and E. Y. Young, 1991. $\mathrm{CuCO}_{3}$ painted containers and root pruning affect on apple and green ash root growth and cytokinin levels. HortScience, 26:242-244.

Backer J. F., N. L. Burrows, A. E. Keohane and L. F. de Fillipiz, 1995. Chemical root pruning of kangaroo paw (Anigozanthos flavidus) by selected heavy metal carbonates. Scientia Horticuture, 62:245-253.

Beeson Jr. R. C., and R. Newton, 1992. Shoot and root responses of eighteen southeastern woody landscape species grown in cupric-hydroxide treated containers. J. Environ. Hort., 10: 214-219.

Devey, C. B., 1984. Pine nursery establishment and operations in the American tropics. In: CAMCORE, Bulletin on Tropical Forestry No.1, Central America and Mexico resources cooperative (CAMCORE), Raleigh, NC, pp. 36.

De Filippis, L. F. and C. K. Pallaghy, 1994. Heavy metals: sources and biological effects. In: L.C. Rai and J.P. Gaur (eds.), Phycological Perspectives of Water Pollution. E. Schweizerbart, Stuttgart.

Hudson, T. H., D. E. Kester., F. T. Dewish and R. L. Geneve, 2002. Plant Propagation: Principles and Practices (seventh edition). New Delhi: Prentice Hall of India Pvt. Ltd.

Saul, G. H., 1968. Copper safely controls roots of tubed seedlings. Tree planters' Note 19(1): 7-9.

Shaw, A. J., 1989. Heavy Metals Tolerance in Plants: Evolutionary Aspects. Boca Raton (FL): CRC Press.

Steel, R. G. D. and J. H. Torrie, 1984. Principles and Procedures of Statistics: A Biometrical Approach (second edition). Singapore: McGraw Hill Book Co.Inc.

Stein, W. L., 1978. Naturally developed seedling roots of five western conifers. In: E. Van Earden and J. M. Kinghorn (eds.), Proceedings of the Root Form of Planted Trees Symposium Victoria, British Columbia, 1619 May, 1978, Joint Report No.8., British Columbia, Ministry of Forests/Canadean Forest Service, pp.28-35.

Struve, D. K., 1993. Effect of copper-treated containers on transplant survival and regrowth of four trees species. J. Environ. Hort. 11(4):196-199.

Struve, D. K., M. A. Arnold, Jr. r. Beeson, J. M. Ruter, S. Svensons and W. T. Witte, 1994. The copper connection. Am. Nurseryman, pp.52-61.

Yeoung, Y. R., S. Y. Shim and J. Y. Jeon, 2001. Effect of copper-coated plug trays on seedling quality and growth of Chinese cabbage (Brassica campestris L.) after transplanting. J. Kor. Soc. Hort. Sci. 42(4): 405-409. 